\title{
The Political and Institutional Impact of Syria's Displacement Crisis: Introduction
}

\author{
Marc Lynch \\ The George Washington University \\ mlynch@gwu.edu
}

\begin{abstract}
Syria's war has since 2011 generated an exceptionally severe displacement crisis. How has the forced movement of millions of Syrians, both within the country and across borders, impacted political institutions and behavior? This symposium examines the political and institutional impact of Syria's displacement crisis through a diverse set of methods and original empirical field research. Contributors explore the changes in the nature of Syria's borders, the effects on Syrian identity, patterns of activism and organization among refugees in Jordan and Lebanon, the dynamics of international attention to Syrian refugees, and the challenges of resettlement in Germany.
\end{abstract}

\section{Keywords}

Syria - refugee - displacement - borders - Jordan - Turkey - Lebanon - Iraq

Since 2011, millions of Syrians have been forced from their homes by the pressures of war. More than 6 million Syrians have fled the country to seek refuge in neighboring countries, with growing numbers moving onward to Europe or other destinations. Another 10 million have been displaced within Syrian borders, relocating along lines of sectarian or ethnic identity and fleeing intense urban warfare. The effects of this displacement crisis are likely to be felt long into the future. The Syrians who have been displaced by war have faced tremendous hardship, with a generation emerging which has known little other than war, trauma and dislocation. The population movements have fundamentally challenged the governance and service capabilities of regional states, the coherence of borders, and the capacity on the international humanitarian order. 
The post-2011 crisis of forced migration in the Middle East is not limited to Syria, of course. Less than a decade after the occupation of Iraq generated a similarly massive refugee and displacement crisis, millions of Iraqis have again been displaced by the 2014 establishment of the Islamic State and the subsequent Coalition war to reclaim Mosul. Many others have fled wars and failed states in Afghanistan, Iraq, Libya, Somalia, Sudan and Yemen. Their movements have been channeled through variably hardened borders, with weaker states such as Libya absorbing huge numbers of refugees and migrants turned away by militarily hardened borders in neighboring states such as Algeria.

It is clear that these mass population movements pose a significant challenge to existing states and to the affected individuals. But how precisely these refugee and displacement flows will shape the region over the longer term is not obvious. The Iraqi refugee crisis of the 2000 s had some lasting effects, but many of the worst case scenarios of cascading state failure and militarized diasporas did not materialize. Some states and communities may crack under the pressure of hosting large refugee populations, but most seem to find ways to absorb and even benefit from their presence. Large refugee populations can put enormous strain on local resources, infrastructure, and employment, but also bring capital, manpower and demand for goods and services. Population movements can challenge the coherence of state borders, but can also lead to more rigorous enforcement and delineation of border practices. Some refugee communities are captured by armed groups or the demands of survival, but others reconstitute political communities and discover new forms of activism. Almost all refugee populations carry scars of mental and physical trauma, but there is wide variation in their ability to access support and health care.

Neighboring states have faced severe challenges in absorbing millions of refugees. The survival of states and resilience of communities can mask deeply significant changes to identity, institutional capacity, and political organization driven by their adaptation strategies. Decisions made to address short term crisis can create long term institutional commitments with decidedly unintended implications. International humanitarian organizations, overwhelmed by the scale and magnitude of these refugee and displacement crises, have become the de facto governing institutions in sizable portions of regional states.

This symposium begins from the premise that capturing the long term effects of the refugee crisis across multiple levels of analysis requires interdisciplinary research. Refugee populations, particularly children, have endured almost unimaginable hardship, dislocation, and loss. Recent research by NGO's such as Save the Children has documented extremely high levels of psychological 
problems among Syrian refugee youth. ${ }^{1}$ Iraq's population has been experiencing similar levels of dislocation and trauma since 2003. Yemen's population has been stunted by near-famine conditions, cholera and other communicable diseases, while Libya's has struggled with the near complete collapse of the state. The effects of these traumas are not necessarily pre-ordained, however. Some societies emerge from such trauma with greater levels of social capital, unified by confronting a common challenge and surviving a common catastrophe. Palestinian society has proven remarkably robust, as identities and communities evolved around the shared experience of dispossession. Jordan has absorbed repeated waves of refugees without suffering the predicted repercussions. Iraq has shown remarkable resilience in the face of a decade and a half of civil war and massive displacement.

This symposium brings together a group of scholars who have worked closely with refugee populations around and from Syria. It is drawn from a larger conference convened by the Project on Middle East Political Science and the University of Southern California's Center for International Studies in February $2017 . .^{2}$ The symposium raises critical theoretical issues which can easily be overlooked in the midst of dealing with an epochal humanitarian crisis. ${ }^{3}$ How has the function of borders changed in response to large scale population movements? How have practices of state sovereignty changed as international organizations take on decisive roles in the provision of services and security? How have refugees and displaced populations organized politically? What ideas about citizenship, community, identity and violence have emerged from these brutal disruptions? How has the internet and a radically new media environment shaped the experience of refugees or their perception in the international community? How has the growing securitization of the refugee crisis affected local and international responses?

Several themes run across the essays in this collection:

1 Invisible Wounds: The impact of six years of war on the mental health of Syria's children. London: Save the Children, 2017; Lina Kreidie, Mahmoud Kreidi and Haya Atassi, "Living With Ongoing Political Trauma: The Prevalence and Impact of PTSD among Syrian Refugees." Psychology Research 6, no. 10 (2016): 598-615; Michelle Slone and Shiri Mann, "Effects of War, Terrorism and Armed Conflict on Young Children: A Systematic Review." Child Psychiatry and Human Development 47 (2016): 95-65.

2 Marc Lynch and Laurie Brand, eds., Refugees and Migration Movements in the Middle East. POMEPS Studies 25 (March 2017).

3 For another excellent roundtable on the topic, see Rafaella A. Del Sarto, "Contentious borders in the Middle East: context and concepts." International Affairs 93, no. 4 (2017): 767-87; Emmanuel Brunet-Jailly, "Theorizing borders: an interdisciplinary perspective." Geopolitics 10, no. 4 (2005): 633-49; Peter Andreas, "Redrawing the Line: Borders and Security in the Twentyfirst Century," International Security 28, no. 2 (2003): 78-111. 


\section{The Changing Nature of Borders}

The institutional functions and capacity of borders in the Levant has been challenged by the magnitude of population movements. The contributions to this symposium show how borders have changed, not disappeared, in response to these new population movements. Middle Eastern borders cannot now be understood as solid barriers between distinct national communities. Instead of thinking of borders as walls, it may be more useful to now think of them as filters, which shape these flows in varying ways by allowing in certain goods and people while excluding others. War economies and the provision of refugee support involve large-scale cross-border networks of people, goods, services and weapons. Sometimes, these borders allow nearly uninterrupted movement into war zones (as with Turkey during much of the Syrian war, or the Islamic State's erasure of the border between Iraq and Syria) and sometimes tightening them to choke off flows (as with Jordan during the Syrian war's later years, or Algeria and Tunisia's response to Libyan and Malian population movements). This variation in border filtering has significant implications for security, political identity, economies and humanitarian well-being.

The essays in this symposium show how each of Syria's neighbors has adopted distinctive new forms of border governance and filtering. ${ }^{4}$ Lebanon's border with Syria has since long before the 2011 crisis exemplified a 'thin' border, with regular movements by Syrian workers, but has taken on new qualities with the arrival of more than a million Syrian refugees. ${ }^{5}$ Iraq's border with Syria served since 2003 as a porous boundary through which insurgents and weapons flowed easily, and was virtually erased by the Islamic State in 2014. Jordan's border was rigorously filtered, allowing refugees in to a carefully controlled environment while establishing a security buffer zone in southern Syria policed by proxy forces. Turkey's remained remarkably open for years, with controls on refugee populations inside Turkey combined with free flowing support for Syrian armed groups and political opposition. No single border captures the "true" essence of Syria's borders.

Something similar can be seen in the Sahel region, where borders have long been difficult to enforce, allowing pervasive smuggling and migration movements. ${ }^{6}$ With the refugee flows driven by the Libyan and Malian wars, and the

4 Samer Abboud, Syria (New York: Polity Press, 2015); Leila Vignal, "The changing borders and borderlands of Syria in a time of conflict," International Affairs 93, no. 4 (2017): 809-27.

5 Simone Tholens, "Border management in an era of 'state-building lite': security assistance and Lebanon's hybrid sovereignty." International Affairs 93, no. 4 (2017): 865-82.

6 Jean-Pierre Cassarino, "Approaching borders and frontiers in North Africa." International Affairs 93, no. 4 (2017): 883-96. 
impact of several bloody Islamic State attacks, Maghrebi states took steps to militarize and secure their borders. Algeria declared an expansive border area as military zones, deploying some 200,000 troops to the region and stranding significant numbers of refugees on the border. ${ }^{7}$ Tunisia received critical military technology and support from the United States and other foreign partners to better secure its borders. The borders of Libya's failed state remained almost completely open, however, controlled by militias and gangs rather than by the state. As a result, Libya became something of a magnet for migration flows, as refugees unable to traverse other North African borders moved towards the more open space.

Transnational political connections, and not only refugees, also unevenly cross these borders. The internationalization of Syria's war was profoundly shaped by the arrival of foreign fighters on both sides, including Shi'ite militias supporting the Assad regime and Sunnis fighting alongside the Islamic State and other armed opposition groups. Much of the information which the West has about the Syrian war was generated by networks of civil society activists, citizens and independent journalists who transmitted information about protests and violence out of the country. Activist networks, as these essays demonstrate, connected these sources and transmitted information across borders in ways which were filtered through motivated actors seeking to shape narratives, promoting agendas and attempting to generate external support for their cause. ${ }^{8}$ Yet another form of border filtering involved the evolution of transnational networks dedicated to the smuggling of migrants as an integral part of this reconfigured state system. ${ }^{9}$ Those cross-border networks are an integral part of the emergent networked structure being shaped by these refugee movements.

\section{The Humanitarian Sector and State Sovereignty}

Refugee populations in states such as Jordan and Lebanon constitute well more than a quarter of the total population, and most are not housed within geographically distinct refugee camps. Turkey's border areas now feature significant areas with Syrian Arab majorities. The enormous strain on their

7 Algeria's South: Trouble's Bellwhether. International Crisis Group Middle East North Africa Report 171 (21 November 2016).

8 Ali Hamdan, "Stretched Thin: Geographies of Syria's Opposition in Exile." Pome ps Studies 26 (2017): $3^{2-36 .}$

9 Luis Achilli, "The Nexus: Human Smuggling and Syrian Refugees' Trajectories across the Middle East and the Balkans." POME Ps Studies 25 (2017): 8-11. 
infrastructure has facilitated the introduction of a semi-permanent presence of international organizations and aid workers into the everyday governance of these noncitizen populations. This long-term role for international organizations in critical areas of economic and social life is challenging core elements of state sovereignty.

States such as Jordan and Lebanon, already poorly equipped to provide security and services such as education, food, health care, and affordable housing to their citizens now face new demands of millions of non-nationals. Many services required by these refugees have been taken on by NGOs and international organizations, creating structures resembling those of state but without any domestic political accountability. These INGOs in many cases have exceptionally high levels of insight into the details of the populations under their care. In cases such as Iraq, the legibility of these populations for INGOs may exceed that of the state, which has essentially abdicated responsibility for this portion of the citizenry. The implications of this long-term insertion of international organizations into state functions, and the potential impact of the withdrawal of such external support after the refugee crisis diminishes in intensity or fades from the international agenda, require considerably more theoretical and empirical investigation.

\section{Political Activism and Organization in Refugee Diasporas}

Contrary to the common image of refugees as passive recipients of aid, there is a surprising amount of activism and political organization among refugee communities. Sometimes these activities focus on the provision of services and the representation of refugee interests within camps, while other activism focuses on supporting the broader war. Given the near-infinite range of urgent needs and possibilities for activism are shaped in part by the physical and social geography of refugee settlements. While Syrian refugees in Turkey and Lebanon have rarely found opportunities to protest or organize politically, Killian Clarke has documented an impressive range of protest activity and political mobilization in Jordan's Za'atari refugee camp. ${ }^{10}$

Many refugees wish for nothing more than to forget politics and build new lives far from the destroyed homeland, of course. Their lives and communities have been disrupted beyond repair, they have suffered unspeakable trauma, and they live in precariously marginal positions at the mercy of local

10 Killian Clarke, "Protest and Informal Leadership in Syrian Refugee Camps." Pom E Ps Studies 26 (2017): 16-21. 
authorities and international organizations. But such marginality and suffering is unlikely to lead to permanent political apathy. The desire for revenge and demands for recognition, no less than material needs, will over the longer term affect political identity and mobilization. As several essays in this symposium make clear, the impact of refugee experience on personal and political identity is not linear.

This raises the question of when the desire for return gives way to local political engagement, blurring the lines between refugee and exile. Given the increasingly networked and transnational structures of politics shaped by these population movements, it is worth asking whether transnational political organizations will emerge to represent and mobilize these dispersed communities. Will there someday be a Syrian equivalent of the Palestine Liberation Organization asserting the right to represent the interests and political demands of the Syrian diaspora, and what would that look like within the constellation of today's Middle East?

\section{The Risks and Inevitability of Securitization}

Prior to 2015, activists and humanitarian NGOs had difficulty generated sustained international concern for the suffering of Syrian refugees despite the extremely high levels of dispossession. Appeals for funding routinely went underfunded, while most attention focused on supporting the efforts of local host states. As the essays in this symposium demonstrate, certain narratives resonate with Western audiences for reasons that have little to do with the lived experiences of the refugees themselves. The logic of an attention economy increasingly shaped by social media gave a distinctive form to the public discourse about refugees from the Middle East. Several of the essays in this symposium point to the iconic image of Aylan al-Kurdi, the Syrian child washed up dead on a beach, as momentarily transformative. Numerous creative social media campaigns, such as the \#WithSyria campaign led by humanitarian NGOs, went viral. But these socially mediated moments rarely led to lasting political or policy change. ${ }^{11}$ This changed only when refugees began reaching Europe in large numbers, and when their presence came to be associated in the public mind with terrorism and nativist backlash.

11 Marc Lynch, "The Problem With \#WithSyria”, Washington Post 14 March 2014 (https://www .washingtonpost.com/news/monkey-cage/wp/2014/03/14/the-problem-with -withsyria/). 
This European reception of the refugee crisis was often framed through populist and xenophobic political narratives. This was turbocharged by the impact of several spectacular terrorist attacks claimed by the Islamic State, which were interwoven in the popular mind with the refugee influx even if refugees themselves had not been involved. The securitization of the refugee problem carried both opportunities and costs. It became possible to mobilize far greater resources, but those resources were primarily directed towards security solutions rather than towards addressing the human needs of traumatized populations.

Historically, refugee camps and communities have often been prime recruiting grounds for jihadist organizations and other extremists. Thus far, Syrian refugee camps seem to have largely avoided this process, but this can not forever be taken for granted. Refugee communities have provided strategic depth and safe harbor for insurgents, but have generally not actually become armed camps or the sites of violent conflict. This mirrors the experience of the Iraqi refugee crisis, where alarmist predictions of conflict spillover and refugee violence largely failed to materialize. ${ }^{12}$ This raises an intriguing question which reverses popular stereotypes: is there something about the Middle East which inhibits the militarization of refugees?

Radicalization may be the issue that most interests governments around the world, but it may not be the most important question for the lives of the millions of displaced citizens. The securitization of the refugee issue, understanding the problem primarily through the lens of security threats and radicalization, carries many hidden costs. Radicalization captures very little of the experience of the vast majority of Syrian refugees. Most refugees are ordinary people struggling to rebuild their lives from the ruins of overwhelming trauma. Treating these refugees primarily as potential security threats, whether through the destabilization of host countries or through recruitment into terrorism, does a profound injustice to their real problems. It could also generate self-fulfilling prophecies, as harsh security measures or strict limitations on immigration push refugees towards alienation and violence. Researchers must find ways to take seriously the challenges posed by large refugee and displaced communities without giving in to the unwarranted securitization of these populations.

12 Reinoud Leenders, "Refugee Warriors or War Refugees? Iraqi Refugees' Predicament in Syria, Lebanon and Jordan." Mediterranean Politics 14, no. 3 (2009): 343-63. 


\section{Conclusion}

The essays in this symposium offer deeply informed perspectives on Syria's refugees. It particularly privileges the voices of young Arab and Syrian scholars, and those who have spent significant time working with Syrian refugees on the ground. These scholars have developed innovative methodologies designed to reach refugee populations, while keeping the ethical issues associated with studying traumatized populations at the center of their approaches. These short essays are meant to be opening statements of new ways to conceptualize and to research the transformative impact of the Syrian displacement crisis. 